\title{
Moral Education and the Condition of Africa
}

\section{Patrick Nyabul}

\author{
Department of Philosophy \& Religious Studies \\ University of Nairobi, Kenya \\ nyabul@yahoo.com
}

Thought and Practice: A Journal of the Philosophical Association of Kenya (PAK)

Premier Issue, New Series, Vol.1 No.1, June 2009, pp.31-42

thoughtandpractice@uonbi.ac.ke OR thoughtandpractice@gmail.com

\begin{abstract}
This paper explores the relationships among moral education on the one hand, and culture, politics, poverty and religion in Africa on the other. It sets out by examining the theory and practice of moral education, before reflecting on moral education and virtue ethics. Thereafter, the paper examines moral education in African cultures and in religion. Finally, it interrogates the connection between moral education in Africa on the one hand, and politics and poverty on the other. The paper concludes that there is still need for a new world order, in which the earth's resources are fairly distributed nationally and globally. For us to realize this goal, we have the task of using politics, culture and religion to foster moral education for the good of everyone.
\end{abstract}

\section{Introduction}

There are many problems in Africa today which could be addressed, partially or wholly, through moral education, among them corruption, poverty, hunger, Aids and war. Morality deals with how humans treat other beings so as to promote mutual welfare, growth, creativity, and meaning, striving for what is good over what is bad and what is right over what is wrong (Thiroux 1998, 28). There are different kinds of morality. For instance, we have individual morality, customary morality, social 
morality and reflective morality (Chatterton-Hill 1971, 185ff). On its part, the lifelong process of education is meant to make us intellectually and morally better. Apart from being knowledgeable, a truly educated person is also expected to be morally competent.

Moral education involves the development of the capacity, knowledge, freedom and willingness to subscribe to ethical values in one's daily decisions and consequent actions. Oduor $(1990,16)$ distinguishes between "moral education" and moral training. For him, the former refers to efforts aimed at helping a child attain an understanding and appreciation of the need for him/her to lead an ethically upright life, while the latter denotes efforts aimed at causing a child to adhere to a set of moral rules regardless of whether or not he/she understands and appreciates the functions of such rules. So understood, moral education affirms the dignity of the human person by encouraging a rational approach to the determination of right and wrong, while moral training dehumanises the individual by indoctrinating him/her into a parrot-like compliance to societal dictates.

This paper explores the relationships among moral education on the one hand, and culture, politics, poverty and religion in Africa on the other. It sets out by examining the theory and practice of moral education, before reflecting on moral education and virtue ethics. Thereafter, the paper examines moral education in African cultures and in religion. Finally, it interrogates the connection between moral education in Africa on the one hand, and politics and poverty on the other. The paper concludes that there is still need for a new world order, in which the earth's resources are fairly distributed nationally and globally. For us to realize this goal, there is need to use politics, culture and religion to foster moral education.

\section{Moral education and Virtue Ethics}

Aristotle offered one of the earliest comprehensive accounts of the content and methodology of moral education, one which remains instructive to date. In Aristotle's moral theory (Aristotle 1985), virtue means excellence of character as well as of intellect. As such, there are two types of virtue, namely, intellectual virtues (or virtues 
of the mind), and moral virtues or virtues of character. The former are acquired by experience, learning, or teaching, the latter through habit. Being intelligent, witty, or having a good sense of humour is considered as a mental or intellectual virtue, while courage, kindness and prudence exemplify virtues of character.

According to Aristotle's doctrine of the Mean, virtue is a relative mean (and not an objective or mathematical mean) between the two extremes of deficiency on the one hand, and excess on the other. On this view then, virtue means moderation. It signifies an activity that is neither too little nor too much in terms of its intensity, but just enough to be good. Sometimes the mean may be more or less in the middle of the two extremities; but at times the mean is closer to one of them. Other factors being equal, one will be virtuous or not virtuous to the extent that one succeeds or fails to achieve the acceptable mean between the extremes; but it may as well be possible to find an excellent person who always attains the mean whenever it is necessary to do so. Such a person serves as an example to others. As far as moral education is concerned, Aristotle has several observations to make.

First, moral education aims at making people morally good, since it is not enough to learn about virtue, but rather to act on what we have learnt, and to translate our knowledge of virtue into action by doing virtuous acts.

Second, in moral education, instruction may benefit only those people who are already enlightened (those whose character has been trained in such a way that they love to do what is right or good, and hate what is bad or wrong), and not everyone else. For many people do not do what is right because they like it, but because they fear punishment. For this reason, arguments may not be useful for them.

Third, moral education encompasses habit, nature and teaching. Aristotle claims that human nature has a divine origin, but habits are acquired by nurture and teaching. "We must already in some way have a character suitable for virtue, fond of what is fine and objecting to what is shameful" (Aristotle 1985, 292).

Fourth, laws are necessary for moral education. They apply to, and are needed by, both children and adults. Laws are required in order to prepare people for training in 
moral education. For, says Aristotle, "it is hard for someone to be trained correctly for virtue from his youth if he has not been brought up under correct laws...laws must prescribe their upbringing and practices."

Fifth, the state should make laws for the sake of morality. Laws are intended for making people to become good.

Sixth, the state is in a better position than individuals as a moral educator, since people are more likely to listen to the state because of its authority rather than to powerless individuals to whom they are bound to become hostile.

Seventh, in some cases, states have abdicated this important responsibility for the moral education of their citizens, and relegated it to individuals. Consequently, individuals are left alone with the responsibility of educating their children and friends.

Eighth, moral education needs legislative science (or the science of making laws), a study which is important for both individuals and states. Good laws are required by everyone.

Ninth, individualized moral education, just like specialized medical treatment, is better than communal moral education or mass education. If individuals experience individualized attention, they are likely to be better educated morally than if they are educated en masse.

Tenth, moral education presupposes knowledge of universal legislative science. Just like professional doctors and coaches need universal knowledge in the areas of their specialization in order to prescribe the right treatment or training to their patients or trainees, so too does the moral educator need universal knowledge of the science of legislation for the moral education and development of the people so as to make them better people (Aristotle 1985, 291ff) 


\section{Moral education "Then" and "Now"}

in view of the many communities that live in Africa, there are a variety of cultures on the continent. Thus Kwasi Wiredu was right in writing about an African culture, and not African culture (Wiredu 1980, 1ff). Culture is a vehicle for the transmission of moral values and moral education. According to a Kiswahili saying, Mwacha mila ni mtumwa ("one who abandons one's culture is a slave"). This is an emphasis on the importance of culture and cultural diversity.

In pre-colonial Africa, moral education was practised as it ought to be, with the parents teaching their children good morals at home. Then there were neither nurseries nor modern-day schools. Instead, elderly people gave instructions to the youth in homes and during the performance of rites of passage. Today, however, such instruction is lacking. Partly because of this negligence and partly because of external influences due to modern science and technology, African cultures have suffered tremendous erosion, and in their place moral decadence has crept in. The task facing us now is how to deal with moral depravity in our midst.

Some African states have shown some commitment to the moral education of their people, as evidenced by their respective school curricula and syllabi. This is especially so at the bottom of the pyramid of the education system, where children are taught subjects such as religious studies and social education. However, in many African countries today, more emphasis seems to be placed on acquiring intellectual knowledge than socio-cultural, moral education. It seems that a lot of effort and time is being spent on learning about scientific and commercially oriented subjects because of their lucrative prospects, to the detriment of moral instruction.

There are many social, economic and political challenges facing Africans today. However, the most pressing ones seem to be political instability, poverty and unemployment. Many people are poor, underemployed or unemployed. There are huge differences and inequalities among people, with regard to the income they get. What Karl Marx said about the newly industrialized European countries of the nineteenth century seems to be applicable to contemporary African societies, that is, the rich get richer while the poor get poorer (Society for International Development 
2006). There is an urgent need to narrow this gap, otherwise social ills might escalate in the future. These socio-economic problems facing Africans have been precipitated, partly because of the mismanagement of resources by those who are charged with the responsibility of their management. This mismanagement, lack of accountability and transparency, can be attributed to lack of a solid moral educational background on the part of the managers.

\section{Moral education in religion}

According to John Mbiti (1987, 1), “Africans are notoriously religious”. Steve Biko adds that "all people are agreed that Africans are a deeply religious race" (Coetzee and Roux 1998, 29). Religion is concerned about morality, though morality is not necessarily concerned about religion. One can be moral without being religious. Morality is related to religion in the sense that the latter teaches people to be moral, since, as in Christianity, for example, morality has its rewards and immorality or sin has its penalties in heaven and hell, respectively, if not here on earth. But Steve Biko thought otherwise when he stated:

It was the missionaries who confused our people with their new religion. By some strange logic, they argued that theirs was a scientific religion and ours was mere superstition in spite of the biological discrepancies so obvious in the basis of their religion. They further went on to preach a theology of the existence of hell, scaring our fathers and mothers with stories about burning in eternal flames and gnashing of teeth and grinding of bone. This cold cruel religion was strange to us but our forefathers were sufficiently scared of the unknown impending anger to believe that it was worth a try. Down went our cultural values! (Coetzee and Roux 1998, 29).

For Judith Boss, "Many people look to religion for moral guidance. The concept of God in the major world religions - Hinduism, Judaism, Christianity, and Islam - is intimately connected with that of moral goodness. People worship God, in part, because God represents perfect goodness. Worshipping reaffirms these moral values. This raises the question of the connection between religion and morality" (Boss 1999, 17-19; see also Plato's Euthyphro). However, as Jacques Thiroux argues, religion need not be based on morality: 
Religion is one of the oldest human institutions. In the earliest times, morality was embedded in the traditions, mores, customs, and religious practices of the culture ... Religion served (as it has until quite recently) as a most powerful sanction for getting people to behave morally. .... The sanctions of tribal reward and punishment pale beside the idea of a punishment or reward that can be more destructive or pleasurable than any that one's fellow human beings could possibly administer. .... there is no necessary connection between morality and religion. The very fact that completely nonreligious people (e.g., humanist ethicists) can evolve significant and consistent ethical systems is proof of this (Thiroux 1998, 21 - 22).

According to Thiroux, there are at least five grounds upon which to challenge the view that morality is based on religion. first, there is no conclusive proof of the existence of a supernatural being. Second, it is possible for non-believers to become moral. Third, religion is not founded on any rational grounds that can serve as the basis of morality. Fourth, even if morality were to be founded on religion, it is difficult to tell, which one among the many conflicting religions, would serve as a basis of morality, and the person who should make that decision. Fifth, the conflict among religious moralities cannot be resolved unless we transcend the religious moralities themselves (Thiroux 1998, 31).

Since the advent of the foreign religions in Africa, a lot of socio-economic and political developments have been achieved. As more clinics, dispensaries, hospitals and schools, colleges and universities have been built, equipped and furnished by various religious organizations, so have more people been employed, treated and educated in these institutions. To be fair to religion, we should not ignore these important achievements.

Nevertheless, there is a sense in which religion divides people. Like education which segregates people into literate, semi-literate and illiterate classes, religion, in Africa, has created social, economic and political differences among people. It has divided people, for example, into Hindus, Muslims, Moonists, Bhuddhists, Christians, African traditional apologists, and atheists. Moreover, at times people of different religious persuasions meddle in politics, deliberately supporting one political party against another, thereby dividing society even further.

However, religion plays a key role in the moral education of young people, in addition to attending to their spiritual needs. As the Luo people say, it is better to straighten a 
plant that is bent while it is still young, than to wait to do so when it reaches maturity, because then it will only snap. This saying is often used to convey the message that it is when people are still young that they can be easily corrected, thereby moulding their character. When people depart from the path of adherence to the doctrines and commandments that are taught by their religion, they may become easy prey to all kinds of influences that are inimical to socio-economic and political progress.

This does not mean, however, that an atheist or an agnostic cannot be moral. In this regard, Boss (1999) has noted:

Most theologians and philosophers maintain that morality exists independently of religion that religious ethics is not fundamentally different from philosophical ethics. Although a moral code is incorporated into the doctrines of most religions, moral issues can be discussed without appealing to religion. When religious people use the terms right and wrong, they generally mean the same things as those who are not religious. Religious differences tend to fall away in most serious discussion of moral issues, such as slavery and abortion, not because religion is not important to the participants, but because moral disputes can be discussed and even resolved without bringing religion into the equation (Boss 1999, 19).

Religion in itself is not undesirable, as it aims at the good of the individual as well as the good of society in general. It is individuals themselves who may be in error. If someone commits a crime, for example, we should not blame the religion he or she belongs to; instead, we should blame the person concerned. It is not religion that spoils a person; rather, it is a person who may spoil the name of an otherwise good religion. Hence we should try as much as possible to avoid the fallacious condemnation of people on the basis of their religion. Discrimination of any kind, be it on the basis of ability, clan, ethnicity, nationality, race, gender, or religion, is wrong because, needless to say, we are all equal as human beings.

Nevertheless, there are instances in which individuals commit certain acts of defiance in the name of religion, as did the crusaders. In such cases, religion goes against morality. Both religion and the adherent are blameworthy in this case - the religion for articulating an antisocial message, the adherent for subscribing to the said message. Adequate moral education can contribute to the reduction of such anti-social beliefs and behaviour. 


\section{Moral education, politics and poverty in Africa}

Although "poverty" and "wealth" are relative terms in the sense that some individuals and some countries are richer or poorer than others, we can talk of them in general terms (Singer 1979, 158ff). In Africa today, there is still excruciating poverty and dazzling affluence. There is ravaging hunger because of poverty. Consequently, children and adults alike suffer from preventable and curable diseases. Poverty undermines cultural traditions. For example, there are people who have been forced by adverse circumstances to feed on the meat of certain animals which they would not eat under normal circumstances.

Absolute poverty is an undesirable condition into which many Africans have been forced by various circumstances, chiefly the encroachment of the individualistic Western culture into their continent. As Julius Kambarage Nyerere observed in his classical Ujamaa (1968), in the African society of the past, the individual was rich or poor only to the extent that the entire society was also rich or poor, since it was a communalistic society (See also Hord and Lee 1995). Impoverishment could only be brought about in the entire community by adverse climate during a particular season. It was never considered repugnant to ask one's neighbour for help if one was struggling (Biko 1998, 28).

Africa can overcome famine and reliance on aid (Ogutu et. al., eds. 1997). Africa, with all its natural resources such as arable land, minerals, rivers and lakes can certainly feed itself. The reasons why it does not do so are obvious. Chinua Achebe has notably said that "the trouble with Nigeria is simply and squarely a failure of leadership" (Achebe 1983, 1). The same thing can be said about many other countries in Africa. Democracy as the government by the people and for the people has become an honorific term depicting an unachievable ideal.

Genuine leadership requires self-sacrifice for the sake of those who are led. Such exemplary leadership is rarely found in our continent. As Aristotle observed, good leaders lead in the interest of their people, but others rule in their own interests. Statesmanship is good leadership. It is disinterested leadership. With the exception of a few gallant African statesmen like Leopold Sedar Senghor, Julius Kambarage 
Nyerere and Nelson Mandela, there is a tendency among our political leaders to refuse to relinquish power, even when it becomes necessary to do so. For instance, a number of them have sought ways and means to perpetuate themselves in power by changing the constitution. People should take turns in leading and being led. The cclaim that some people were born to become leaders while others were born merely to become their followers is not true, unless we are talking about a monarchy, with princes and princesses to whom power is bequeathed naturally.

Aristotle noted that good constitutions serve the interests of the majority, while bad ones serve the interests of rulers. States have come into existence for the good of everyone, and for the fulfilment of the noble goal of living a good life worthy of a dignified human being. The success or failure of states depends, therefore, on the extent to which they approach this ethical ideal. Thus citizens' Eudaimonia (or happiness) should be the state’s raison d'etre; but many people in Africa are far from being happy, because of poverty and problems associated with leadership.

There is need for a truly new world order. Something is certainly wrong with the categorization of countries into the three distinctive groups of First world, Second world, and Third world. Gonsalves $(1985,502)$ is right when he says that "the problem, of which the malnourished and starving poor are the symptoms, is in the economic and political orders of the world's societies". For instance, rarely does the food meant for hungry people in underdeveloped countries reach them, as it is swindled by middlemen, who auction it to the highest bidder. This is corruption. Kwame Gyekye calls it "moral pollution", while Oriare Nyarwath attributes it to “moral ignorance” (See Gyekye 1997, 192 and Presbey et. al. eds., 2002).

A Kenyan politician once said that we should not build a nation of ten millionaires and ten million beggars. He was talking about the problem of poverty. People who are morally educated will not take advantage of their fellow humans by engaging in acts of corruption and other social ills. We therefore need moral education in order to reduce, if not eliminate, social, economic and political evils. 


\section{Conclusion}

Africa's political, cultural and religious leaders, by virtue of their privileged positions, have the onerous responsibility of pointing out the way to truly humane societies. For political societies came into existence, in the first place, to enable people to lead the good life. In order for this noble goal to be achieved, there is need for a truly new world order, in which resources are shared equitably at both the local and global levels. This is due to the fact that absolute poverty is one of the consequences of moral depravity on the part of those who manage society's resources.

In view of the foregoing discussion, we may conclude that moral education is necessary for Africa's social, economic and political development. If we know the right action, we are more likely to practice it than if we do not know it. Teaching Moral education, particularly in schools, while the learners are still young and malleable, can help in moulding their character. Yet in many African countries, schools have no curricula for moral education. This can partly account for the many moral offences that plague our societies, among which are tribalism, nepotism and corruption. Consequently, moral education should be introduced where it is lacking, and reinforced where it has already been introduced.

\section{References}

Achebe, C. 1983. The Trouble with Nigeria. Nairobi: Heinemann.

Aristotle. 1985. Nicomachean Ethics. Irwin, Terence, trans. Cambridge: Hackett Publishing Company.

Boss, J. 1999. Analyzing moral Issues. Toronto: Mayfield Publishing Company.

Chatterton-Hill, G. 1971. The Philosophy of Nietzsche: An Exposition and an Appreciation. New York: Haskell House Publishers Ltd.

Coetzee, P.H. and A.P.J. Roux eds. 1998. Philosophy from Africa: A text with Readings. Johannesburg: International Thomson Publishing Company.

Gonsalves, M.A. 1985. Fagothey's Right and Reason: Ethics in Theory and Practice.. Columbus: Charles E. Merril Publishing Company.

Gyekye, K. 1997. Tradition and Modernity: Philosophical Reflections on the African Experience. New York: Oxford University Press.

Hord, F.L. and Jonathan Scott Lee. 1995. I Am Because We Are. University of Massachusetts Press.

Mbiti, J. 1987. African Religions \& Philosophy. Nairobi: Heinemann Kenya Limited. 
Nyerere, J. 1968. Ujamaa: Essays on Socialism. Cambridge: Cambridge University Press.

Oduor, Reginald M.J. 1990. "Social Education and Ethics Programme: Its Main Sources and their justifications in Post-Colonial Kenya". M.A. Thesis, Kenyatta University.

Ogutu, G. et. al. eds. 1995. Futures Beyond Poverty: Ways and Means out of the Current Stalemate: Selections from the XIV World Conference of World Futures Studies Federation, Nairobi, Kenya, July 25-29. Turku: Finland Futures Research Centre

Presbey, G. et. al. Eds. 2002. Thought and Practicer in African Philosophy: Selected papers from the sixth annual conference of the International Society for African Philosophy and Studies (ISAPS). Nairobi: Konrad Adenauer Foundation.

Singer, P. 1990. Practical Ethics. Cambridge: Cambridge University Press

Society for International Development . 2006. Readings on Inequality in Kenya: Sectoral Dynamics and Perspectives. Nairobi: SID

Thiroux, J. 1998. Ethics: Theory and Practice. Upper Saddle River: Prentice Hall.

Tinyiko S. M.2007. "Biko on religion and black liberation". South African Council of Churches. http://www.sacc.org.za/news07/biko.html

Wiredu, K. 1980. Philosophy and an African Culture. Cambridge: Cambridge University Press. 